\title{
Dimensi Spiritualitas dalam Kompetensi Kepribadian Guru Pendidikan Agama Kristen
}

\author{
Delipiter Lase E Etty Destinawati Hulu \\ STT Banua Niha Keriso Protestan Sundermann Nias \\ piterlase@sttsundermann.ac.id
}

\section{ARTICLE INFO}

Submitted: Click or tap to enter a date

Review: Click or tap to enter a date

Accepted: Click or tap to enter a date

Published: Click or tap to enter a date

\section{KEYWORDS}

spirituality, Christian religious education teacher, personality competence

\section{CORESPONDENCE}

\section{Phone:}

E-mail:

\begin{abstract}
A B S T R A C T
This article discusses the dimensions of spirituality in the personal competence of Christian Religious Education (CRE) teachers. Spirituality is essential because the teaching that CRE teachers do aims to improve the spirituality of their students. He should have good spirituality so that he can be an example in his teaching. In this paper, the author explaining the essential values of spirituality that must be possessed by a CRE teacher in order to fulfill his calling as someone who has a profession as a teacher. To arrive at this goal, the authors develop the essential values of spirituality by conducting literature studies and content analysis methods. Based on a search from various sources, including the nature of spirituality, according to Christianity, the author explains the essential spiritual values that must be possessed by a CRE teacher. The essential values of spirituality are grouped into two dimensions, namely the personal dimension and the relational dimension.
\end{abstract}

\begin{abstract}
A B S TRAK
Artikel ini membahas tentang dimensi spiritualitas dalam kepribadian guru pendidikan agama Kristen. Spiritualitas menjadi sangat penting karena pengajaran yang guru pendidikan agama Kristen lakukan bertujuan untuk meningkatkan spiritualitas peserta didiknya. Ia mesti memiliki spiritualitas yang baik sehingga ia dapat menjadi teladan dalam pengajarannya. Dalam tulisan ini, penulis berupaya memaparkan nilai-nilai esensial spiritualitas yang harus dimiliki oleh seorang guru PAK dalam rangka memenuhi tugas panggilannya sebagai seseorang yang memiliki profesi sebagai guru. Untuk boleh sampai pada tujuan tersebut, penulis mengembangkan nilai-nilai esensial spiritualitas itu, dengan melakukan kajian litaratur dan analisis isi. Berdasarkan penelusuran dari berbagai sumber, termasuk di dalamnya hakikat sipritualitas dari sudut pandang Kekristenan, penulis memaparkan nilai-nilai esensial spiritual yang harus dimiliki seorang guru PAK. Nilai-nilai esensial spiritualitas tersebut dikelompokkan ke dalam dua dimensi, yakni dimensi personal dan dimensi relasional.
\end{abstract}

Kata kunci: spiritualitas, guru pendidikan agama Kristen, kompetensi kepribadian

\section{PENDAHULUAN}

D i lingkungan sekolah seorang guru PAK selain diharapkan menjadi pengajar yang baik, ia juga diharapkan mampu berperan layaknya seorang rohaniawan. Harapan itu terlihat dalam realita di lapangan, di mana seorang guru PAK seringkali diberi beban tugas oleh pihak sekolah sebagai (1) Pengkhotbah atau 
pembawa renungan dalam kegiatan-kegiatan keagamaan di lingkungan sekolah,

Koordinator kegiatan sosial baik suka mau pun duka dalam lingkup keluarga besar sekolah dan

(3) Penasehat bagi pihak sekolah dalam pengambilan keputusan.

Kondisi ini menunjukkan bahwa ekspektasi terhadap seorang guru PAK sangat tinggi. Ia dituntut untuk mampu melakukan berbagai peran serta memiliki spiritualitas tinggi yang terlihat melalui perkataan, sikap dan perilaku yang dapat diteladani. Spiritualitas menjadi salah satu aspek penting yang harus dimiliki oleh seorang guru PAK. Hal ini disebabkan: pertama, karena tugas mendidik bukanlah pekerjaan yang hanya bersifat teknis dan mekanik; kedua, karena pendidik Kristen menghadapi tantangan pluralisme nilai, kepercayaan dan spiritualitas. Bahkan lebih dari itu spiritualitas seorang guru PAK menjadi sangat penting karena pengajaran yang dilakukannya sendiri bertujuan untuk meningkatkan spiritualitas peserta didik. Oleh karena itu guru PAK mesti memiliki spiritualitas yang baik sehingga ia dapat menjadi teladan dalam pengajarannya.

Spiritualitas seseorang yang mengajarkan firman Tuhan juga ditekankan oleh firman Tuhan sendiri yang terdapat dalam Titus 2:7-8 “...dan jadikanlah dirimu sendiri suatu teladan dalam berbuat baik. Hendaklah engkau jujur dan bersungguh-sungguh dalam pengajaranmu ..." Di sini Paulus menasihatkan kepada Titus yang ditugaskannya di pulau Kreta untuk menjadi teladan dalam perbuatan baik sesuai dengan firman Tuhan yang diajarkannya. Titus dituntut untuk terlebih dahulu hidup sesuai dengan firman Tuhan yang diajarkannya sebelum mengajar orang lain. Keteladanan merupakan tindakan praktis dari sikap hidup baik, yang harus Titus perlihatkan kepada orang lain untuk diamati.

Harapan yang begitu tinggi tentang guru PAK yang memiliki spiritualitas yang baik, ternyata juga tidak selamanya berlaku. Di sekolah-sekolah tertentu (kasuistik), penulis menemukan bila masih terdapat guru PAK hanya mentransfer pengetahuan kepada siswa, tetapi tidak menunjukkan kerohanian yang patut dicontoh melalui sikap dan perilaku.

Ketidaksesuian ini terjadi dengan berbagai alasan, di antaranya guru PAK tidak sepenuhnya menyadari bahwa salah satu kompetensi yang harus dimiliki adalah kompetensi spiritual. Guru PAK seringkali memahami dirinya setara atau sama seperti guru mata pelajaran lainnya. Tidak semua guru PAK memiliki kemampuan untuk berkhotbah, menafsirkan firman Allah dan menjadi gembala bagi peserta didiknya. Realita ini menunjukkan bahwa nilai-nilai spiritualitas belum sepenuhnya terinternalisasi dalam diri guru PAK.

Nilai-nilai spiritualitas yang belum sepenuhnya terinternalisasi dalam diri guru PAK menimbulkan ketidaksesuaian antara konsep yang diajarkan dengan praktiknya. Akibatnya peserta didik tidak memperoleh keteladanan spiritual dan aspek spiritual dalam dirinya juga tidak dapat disentuh oleh guru PAK.

Bertolak dari uraian di atas, tulisan ini ditujukan untuk menjelaskan dimensi spiritualitas dalam kompetensi kepribadian guru Pendidikan Agama Kristen, serta upaya internalisasi nilai-nilai yang dikandungnya.

\section{HAKIKAT SPIRITUALITAS}

Banyak orang yang mengartikan spiritualitas dalam definisi yang sempit dan terbatas hanya pada aktivitas keagamaan saja. Ada orang yang mengartikan spiritualitas terbatas kepada tindakan orang-orang yang bertapa di tempat-tempat sepi dan khusus. Ada juga yang berpandangan bahwa orang-orang yang rajin beribadah dan terlibat dalam berbagai kegiatan keagamaan adalah orang-orang spiritual; orang yang memiliki kemampuan supranatural dianggap sebagai orang yang memiliki derajat spiritualitas tinggi. Bahkan banyak orang yang berpendapat bahwa hambahamba Tuhan seperti pendeta, pastor, alim ulama, biksu, dan sebagainya pasti orang spiritual.

Menurut Rahmiati Tanudjaja, ada beberapa tolok ukur yang sering dipakai oleh orang Kristen pada zaman ini untuk mengukur spiritualitas seseorang. Pertama, keterlibatan seseorang dalam aktivitas-aktivitas kerohanian. Kedua, keterlibatan seseorang dalam berbagai pelayanan sosial. Ketiga, penampakan fenomena supranatural melalui kehidupannya. Keempat, penampakan pola hidup yang menjauhkan diri dari kegiatan "duniawi". Kelima, pemakaian atribut kristiani, misalnya orang yang selalu bawa Alkitab, pakai aksesori, atau selalu 
mendengarkan lagu-lagu Kristen dianggap lebih cinta Tuhan dari yang tidak memakainya. ${ }^{1}$

Akan tetapi ukuran di atas tidaklah dapat dikatakan sebagai tolok ukur yang tepat karena spiritualitas sejati tidak berpusat pada kegiatan keagamaan yang superfisial, dan spiritualitas sejati tidak didasari pada tatanan nilai moral serta kewajiban-kewajiban di dalamnya.

Akibat pemahaman yang sempit dan terbatas ini, pengertian spiritualitas mengalami pergeseran dan semakin tidak jelas. Hal ini disebabkan karena pada kenyataannya ada orang-orang yang aktif dalam kegiatan-kegiatan keagamaan justru memiliki perilaku sehari-hari yang tidak baik, dan sebaliknya juga orang-orang yang biasa-biasa saja dalam mengikuti kegiatankegiatan keagamaan justru memiliki spiritualitas yang baik. Bahkan tidak tertutup kemumgkinan, pemahaman yang sempit dan terbatas ini menyebabkan terjadinya perilaku menyimpang, misalnya ketika tindakan terorisme dengan meledakkan bom di rumah-rumah ibadah atau di tempat-tempat umum yang dikenal dengan istilah 'jihad' diyakini sebagai bentuk dari spiritualitas; atau misalnya ketika tindakan korupsi dan kemudian membagikannya kepada orang miskin yang membutuhkan dianggap sebagai tindakan spiritual.

Selama beberapa dekade terakhir, istilah spiritualitas telah memasuki bahasa umum sebagai cara alternatif untuk menggambarkan pencarian kita akan transendensi. ${ }^{2}$ Dalam bahasa

${ }^{1}$ Rahmiati Tanudjaja, “Anugerah Demi Anugerah Dalam Spiritualitas Kristen Yang Sejati," Veritas, no. 2 (October) (2002): 171-182.

2 Ana-María Rizzuto, "Psychoanalytic Considerations about Spiritually Oriented Psychotherapy.," in Spiritually Oriented Psychotherapy. (Washington: American Psychological Association, 2005), 31-50, http://content.apa.org/books/10886-002.

3 Brian J. Zinnbauer et al., "Religion and Spirituality: Unfuzzying the Fuzzy," Journal for the Scientific Study of Religion 36, no. 4 (December 1997): 549, https://www.jstor.org/stable/1387689?origin=crossref.

4 Eugene C. Roehlkepartain et al., "Spiritual Development in Childhood and Adolescence: Moving to the Scientific Mainstream," in The Handbook of Spiritual Development in Childhood and Adolescence, ed. E. Roehlkepartain and P. King (2455 Teller Road, Thousand Oaks California 91320 United States: SAGE Publications, Inc., 2006), 1-15, http://sk.sagepub.com/reference/ hdbk_childspiritdev/n1.xml.

${ }^{5}$ E. Lewis, "Posture as a Metaphor for Biblical Spirituality," in The Destructive Power of Religion: Violence
Inggris, "spiritual" adalah istilah yang digunakan untuk membedakan kehidupan gereja dengan cara alami atau materialistis. Pada abad ke-19, "spiritualitas" bukanlah istilah yang umum digunakan, dan "Spiritualisme" merujuk pada kontak dengan roh dan fenomena psikis lainnya. Dalam penggunaan kontemporer, istilah ini memiliki beberapa arti umum, ${ }^{3}$ dan definisi dalam literatur ilmiah juga bervariasi. Perbedaan-perbedaan ini mencerminkan fakta bahwa spiritualitas adalah istilah luas yang mencakup berbagai bidang makna yang mungkin berbeda di antara berbagai kelompok budaya, nasional, dan agama. ${ }^{456}$

Saat ini istilah ini sering digunakan untuk menunjukkan pengalaman dan sisi pribadi dari hubungan kita dengan yang transenden atau sakral $^{7}$ (lih. Peter C. Hill et al. ${ }^{8}$; Emmons \& Crumpler ${ }^{9}$. Mereka yang menggunakan istilah dengan cara ini biasanya kontras dengan agama, yang secara sempit mereka definisikan sebagai struktur organisasi, praktik, dan kepercayaan kelompok agama. Di lain sisi, para teolog dan praktisi agama cenderung lebih menyukai definisi yang kurang menarik tentang pemisahan ketat antara agama dan spiritualitas. Di mata mereka, spiritualitas adalah realitas kehidupan beragama yang dialami oleh penganut tradisi.

Philip Sheldrake dalam bukunya Spirituality and History mendefinisikan spiritualitas sebagai "the conscious human response to God that is both personal and ecclesial." ${ }^{10}$ Lebih lanjut dikatakan

in Judaism, Christianity and Islam, ed. J. Ellens, vol. 4 (Westport, CT: Praeger, 2004), 143-174.

6 Masami Takahashi and Satoshi Ide, "Implicit Theories of Spirituality across Three Generations: A Cross-Cultural Comparison in the U.S. and Japan," Journal of Religious Gerontology (2003).

7 James M. Nelson, Psychology, Religion, and Spirituality, ed. James M. Nelson (New York, NY: Springer New York, 2009), http://link.springer.com/ 10.1007/978-0-387-87573-6.

${ }^{8}$ Peter C. Hill et al., “Conceptualizing Religion and Spirituality: Points of Commonality, Points of Departure," Journal for the Theory of Social Behaviour (2000).

9 Robert A. Emmons and Cheryl A. Crumpler, "Religion and Spirituality? The Roles of Sanctification and the Concept of God," The International Journal for the Psychology of Religion 9, no. 1 (January 16, 1999): 17-24, http:/ / www.tandfonline.com/doi/abs/10.1207/s15327 582ijpr0901_3.

${ }^{10}$ Philip Sheldrake, "Spirituality: A Brief History," in Statewide Agricultural Land Use Baseline 2015, 2nd ed. (Somerset, New Jersy: John Wiley and Sons, 2013), 23-46. 
bahwa "Christian spirituality embodies a conscious relationship with God, in Jesus Christ, through the indwelling of the Spirit, in the context of a community of believers (spiritualitas Kristen mewujudkan hubungan yang sadar dengan Tuhan, dalam Yesus Kristus, melalui berdiamnya roh, dalam konteks komunitas orang percaya)."11 Eka Dharmaputra memahami bahwa spiritualitas adalah roh, jiwa, semangat dan gairah. Spiritualitas menempati rangking teratas dalam skala prioritas. Ibarat gereja yang mempunyai segala macam dan segala sesuatu: gedung gereja, pendeta, kegiatan-kegiatan, keuangan, aktivitas yang banyak, tetapi tanpa spiritualitas yaitu roh, jiwa, semangat dan gairah, maka semuanya itu akan berubah menjadi sekedar sebuah rutinitas gereja semata. ${ }^{12}$

Sementara itu, Eliade menyatakan bahwa spiritualitas Kristen adalah cara hidup Kristen yang merupakan ibadah dan pengembangan hubungan dengan Kristus. ${ }^{13}$ Artinya spiritualitas Kristen merupakan hasil relasi antara manusia dengan Kristus yang kemudian diwujudkan dalam cara hidup orang Kristen sehari-hari yang meneladani Kristus. Relasi yang baik antara manusia dengan Kristus, akan memampukan orang tersebut untuk bersikap dan berperilaku baik dalam kehidupannya, mengasihi sesamanya dan mengampuni.

"Christian spirituality concerns the quest for a fulfilled and authentic Christian existence, involving the bringing together of the fundamental ideas of Christianity and the whole experience of living on the basic of and within the scope of the Christian faith." 14 Pandangan McGrath ini menyiratkan bahwa spiritualitas Kristen dapat dipahami sebagai cara yang telah dikembangkan oleh orang-orang Kristen, baik secara individu maupun dalam kelompok untuk memperdalam pengalaman mereka dengan Tuhan, atau mempraktikkan "kehadiran Tuhan." Sehingga spiritualitas Kristen dimanifestasikan dalam bentuk doa kepada Tuhan, refleksi pribadi, pujian, dan penyembahan kepada Tuhan melalui nyanyian, meditasi, dan juga melalui perilaku hidup yang

11 Philip Sheldrake, The New SCM Dictionary of Christian Spirituality (SCM Press, 2005).

12 Eka Darmaputera, Spiritualitas Siap Juang (Jakarta: BPK Gunung Mulia, 2011), 207.

${ }^{13}$ Mircea Eliade, The Encyclopedia of Religion, 3rd ed. (New York: Macmillan Publishing, 1986), 452.

14 Alister E. McGrath, Christian Spirituality: An Introduction (Oxford: Blackwell Published, 1999), 2. baik sebagai buah Roh dalam kehidupan orang Kristen.

Sementara itu, Victor Tanja menyatakan bahwa spiritualitas kristiani adalah sikap hidup yang berbuahkan kasih, sukacita, damai, sejahtera, kesabaran, kemurahan, kebaikan, kesukaan, kelemah-lembutan, dan penguasaan diri. Spiritualitas kristiani adalah ungkapan sikap hidup yang selalu berkarya, karena dengan berkarya itulah hidup kita menghidupkan orang lain serta membawakan kebaikan bagi semua orang yang pada dasarnya adalah sesama ciptaaan Tuhan. ${ }^{15}$ Dari pernyataan Victor Tanja tersebut dapat disimpulkan bahwa spiritualitas Kristen adalah sikap dan cara hidup orang-orang Kristen yang membawa kebaikan bagi orang lain yang ada di sekitarnya.

Spiritual merupakan suatu istilah kristiani. Paulus memakai kata untuk pertama kali, sewaktu ia menyebut orang kristiani "orang rohani", karena mereka hidup dipimpin oleh Roh (bdk. 1 Kor. 2:15; 3:1; 5:3). Namun kini kata "spiritualitas" dipakai umum untuk kemampuan manusia dalam transendensi diri (selftranscendence) tanpa memperhatikan apakah transendensi diri itu bersifat religius atau tidak. ${ }^{16}$

Dalam lingkup akademik, spiritualitas (spiritual quotient) dibahas secara ilmiah oleh Danah Zohar (seorang psikolog) dan Ian Marshall (seorang fisikawan) dalam buku berjudul SQ: Spiritual Intelligence - The Ultimate Intelligence (2000). Buku tersebut membahas tentang kecerdasan spiritual sebagai faktor penentu bagi keefektifan kecerdasan intelektual dan kecerdasan emosi. Zohar mendefinisikan kecerdasan spiritual sebagai kecerdasan untuk menghadapi dan memecahkan persoalan makna dan nilai, yaitu kecerdasan untuk menempatkan perilaku dan hidup kita dalam konteks makna yang lebih luas dan kaya; kecerdasan untuk menilai bahwa tindakan atau jalan hidup seseorang lebih bermakna dibandingkan dengan yang lain. SQ adalah landasan yang diperlukan untuk mengfungsikan IQ dan EQ secara efektif.

15 Widi Artanto, "Spiritualitas Pelayanan: Perjumpaan Dengan Allah Dan Sesama," in Pelayanan, Spiritualitas Dan Pelayanan, ed. Asnath N. Nathar (Yogyakarta: Taman Pustaka Kristen, 2012), 7.

${ }^{16}$ V. Wahyu Harjanto, Berbakti Dengan Spirit Dan Nalar: Spiritualitas Atau Teologi? Orientasi Baru, Jurnal Filsafat Dan Teologi (Yogyakarta: Kanisius, 2001), 110. 
Bahkan SQ merupakan kecerdasan tertinggi kita. ${ }^{17}$

Di sini Zohar mengaitkan SQ dengan IQ dan EQ. IQ yang tinggi memampukan seseorang untuk berpikir dan EQ memampukan seseorang untuk mengambil keputusan untuk bersikap tepat sesuai dengan kondisi yang dihadapinya, maka SQ memampukan seseorang untuk memutuskan apakah ia mau berada di dalam situasi seperti itu. Jadi IQ dan EQ bekerja dalam batasan situasi, sedangkan SQ memampukan seseorang untuk dapat mengubah atau memperbaiki situasi yang dihadapinya.

Margot Cairnes, seorang pakar pendidikan memberikan definisi yang mengkonfirmasi pernyataan Zohar dengan mengatakan bahwa SQ adalah kemampuan seseorang untuk bertanya, berpikir dengan kreatif, mengubah aturan-aturan, bekerja dengan efektif dalam situasi yang berubah melampaui batasanbatasan yang ada, menembus halanganhalangan yang ada dan membuat inovasi. ${ }^{18}$ Pendapat Cairnes ini menunjukkan bahwa kecerdasan spiritual adalah kemampuan dalam diri seseorang untuk mengubah atau memperbaiki suatu situasi tertentu secara kreatif dan inovatif agar menjadi lebih baik.

Dari pendapat di atas terlihat bahwa orang yang kecerdasan spiritualnya baik, dapat memahami perasaan orang lain, dapat membaca yang tersurat dan yang tersirat, dapat menangkap bahasa verbal dan nonverbal, dapat memperlakukan orang lain dengan baik sebagaimana ia juga ingin diperlakukan baik. Pemahaman-pemahamannya tersebut akan menuntunnya untuk bersikap dan bertindak sesuai dengan kebutuhan dan tuntutan lingkungannya. Dengan kata lain kecerdasan spiritual dapat membantu seseorang untuk merespon tuntutan lingkungannya dengan tepat. Juga, menunjukkan secara eksplisit bahwa kecerdasan spiritual memiliki keterkaitan dengan kepercayaan seseorang terhadap Tuhannya, atau tidak terlepas dari agama yang diyakini. ${ }^{19}$

${ }^{17}$ Zohar \& Marshall and Jenny King, “SQ: Spiritual Intelligence: The Ultimate Intelligence," Psychology and Psychotherapy 75, no. January (2002): 116-117.

18 Tanudjaja, "Anugerah Demi Anugerah Dalam Spiritualitas Kristen Yang Sejati."
Dalam Alkitab, spiritual yang berasal dari kata spirit ditulis dalam bahasa asli: ruakh (Ibrani) dan pneuma (Yunani). Arti kata ruakh atau pneuma dalam Alkitab adalah "nafas atau angin yang menggerakkan dan menghidupkan". Pengertian ini sama dengan pengertian kata spirit yang sering kita pakai sesehari, yaitu 'semangat'. Semangat atau spirit yang kita butuhkan untuk bergerak dan hidup. Semangat atau spirit ini hanya kita miliki di dalam Holy Spirit (Roh Kudus). ${ }^{20}$

Selanjutnya dalam pemahaman agama Kristen, spiritualitas berawal pada saat seseorang percaya dan menerima Yesus sebagai Juruselamat pribadinya. Orang tersebut diberi kuasa oleh Allah sebagaimana telah dinyatakan dalam firman Tuhan, "Tetapi semua orang yang menerima-Nya diberi-Nya kuasa supaya menjadi anak-anak Allah, yaitu mereka yang percaya dalam nama-Nya; orang-orang yang diperanakkan bukan dari darah atau dari daging, bukan pula secara jasmani oleh keinginan seorang laki-laki, melainkan dari Allah" (Yoh. 1:12-13). Ayat ini menjelaskan bahwa setiap orang percaya, diberi kuasa oleh Allah untuk menjadi anak-anak Allah yang bersikap dan hidup seturut dengan kehendak Allah. Sikap dan cara hidup yang seturut dengan kehendak Allah itulah yang disebut dengan spiritualitas Kristen.

Dari pendapat-pendapat para ahli di atas, penulis berpendapat bahwa spiritualitas merupakan suatu keadaan atau sifat rohaniah menyangkut hubungan dan ketaatan yang total seseorang yang beriman kepada Allah. Hubungan dan ketaatan yang total tersebut mengalirkan semangat dan dorongan dalam diri orang tersebut untuk berpikir, berkata-kata, bersikap dan berperilaku sesuai dengan ajaran/perintah Allah yang diimaninya.

\section{METODE}

Untuk mengembangkan konsep yang relevan dengan topik, penulis melakukan tinjauan literatur yang diperoleh dari buku dan jurnal ilmiah, laporan penelitian, esai ilmiah,

19 Etty Destinawati Hulu, "Spiritualitas Guru Pendidikan Agama Kristen Dan Pengaruhnya Terhadap Pencapaian Tujuan Pembelajaran" (STT Banua Niha Keriso Protestan Sundermann Nias, 2014).

20 Artanto, "Spiritualitas Pelayanan: Perjumpaan Dengan Allah Dan Sesama," 7. 
tesis dan disertasi, ensiklopedi dan sumber cetak dan elektronik lainnya. Lebih lanjut, bahwa untuk mendapatkan karakteristik yang jelas dari wacana berupa teori dan konsep yang dikaji, penulis menggunakan metode content analysis, yakni suatu teknik penelitian untuk membuat inferensi yang dapat direplikasi dan sahih datanya dengan memerhatikan konteksnya. ${ }^{2122}$

\section{DIMENSI SPIRITUALITAS GURU PAK}

Sebelum menjelaskan dimensi spiritualitas dalam kompetensi kepribadian guru PAK, perlu terlebih dahulu memahami esensi pendidikan agama Kristen.

PAK merupakan pengajaran kepada seseorang untuk mengenal siapakah Yesus Kristus dan memiliki iman yang sungguhsungguh kepada Yesus Kristus. Dengan demikian PAK adalah mengajarkan pengetahuan dan pandangan-pandangan, keyakinan, dogma atau teologi yang dimiliki oleh seseorang tentang Yesus Kristus. PAK yang diberikan harus merupakan sebuah kebenaran, yang sesuai dengan koridor firman Tuhan yang bersifat prinsip dan mendasar dalam PAK itu sendiri. PAK merupakan suatu sarana yang sangat penting dalam mempersiapkan seseorang untuk menghadapi masa yang akan datang. Itu sebabnya, mutu dari pengajar (para pendidik) harus senantiasa ditingkatkan. Peningkatan tersebut bukan hanya peningkatan dalam hal teori saja, tetapi pengajar PAK juga harus mengalami peningkatan secara spiritualitas, dalam pengertian ia bertumbuh dan hidup sesuai dengan apa yang diajarkannya kepada naradidiknya.

Oleh karena itu, PAK mesti memiliki landasan atau dasar teologis. Landasan atau dasar teologis ini merupakan pengarah tugas bagi pendidikan itu sendiri. Setidaknya terdapat enam landasan teologis yang menjadi unsur penting dalam kegiatan PAK, yaitu: ${ }^{23}$

1. Pengenalan akan Allah;

2. Pandangan mengenai kedudukan dan fungsi Alkitab;

21 Klaus Krippendorff, Content Analysis: An Introduction to Its Methodology (Second Edition), SAGE Publications, 2004.

22 Rachmat Kriyantono, Teknik Praktis Riset Komunikasi, 6th ed. (Jakarta: Kencana Prenada Media Grup, 2012), 232-233.
3. Pengenalan terhadap Yesus Kristus;

4. Roh Kudus dan pranan-Nya;

5. Manusia, kedudukan dan panggilan; dan

6. Kedewasan.

Berdasarkan uraian di atas, maka hakikat PAK dapat dipahami lebih luas dari sekedar pengajaran, asuhan, sosialisasi dan enkulturasi. PAK sebagai sebuah konsep pendidikan memiliki asumsi tentang usaha yang dilakukan secara sadar, tersistemik dan berkesinambungan. Namun pendidikan itu dikhususkan pada dimensi religius dari kehidupan manusia. Lebih jauh lagi penambahan kata 'Kristen' pada istilah tersebut menegaskan bahwa pendidikan dalam dimensi religius dari kehidupan manusia ini dilakukan dari perspektif agama Kristen, dengan konteks dan muatan kekristenan.

\section{Guru Pendidikan Agama Kristen}

Siapakah Guru PAK? Dalam Undangundang No. 14 Tahun 2005 tentang guru dan dosen, dikatakan bahwa guru adalah pendidik profesional yang mendidik, mengajar, membimbing, mengarahkan, melatih, menilai, dan mengevaluasi peserta didik pada Pendidikan Anak Usia Dini pada jalur pendidikan formal, pendidikan dasar dan menengah. Dengan demikian dapat dipahami bahwa guru adalah seseorang yang memiliki keahlian, kecakapan dan ketrampilan yang menjalankan tugasnya secara profesional pada pendidikan formal mulai dari pendidikan terendah hingga tingkat pendidikan menengah.

Guru adalah orang yang memiliki pengetahuan yang lebih banyak sehingga dia lebih pandai daripada murid-muridnya. Guru memiliki keterampilan memberi instruksi dalam proses belajar-mengajar dan mendidik. Guru mengajar melalui mulutnya, melalui raut wajahnya (mimik), melalui gerak anggota badannya (pantomimik), melalui bahasa isyarat baik sadar atau tidak sadar, melalui sikap dan sifatnya: sopan, ramah, peduli, tanggap, tegas, teliti, rapi, bersih, berani, disiplin, cerdas, cermat, cekatan, trampil, dan sebagainya. Guru ditiru

23 B. S Sidjabat, Mengajar Secara Profesional: Mewujudkan Visi Guru Profesional (Yayasan Kalam Kudus, 2009). 
dan digugu oleh murid. Oleh karena itu guru idealnya menjadi teladan bagi murid-muridnya. Rasul Paulus menulis surat kepada Timotius dan ini juga relevan bagi para guru, yaitu menjadi teladan dalam hal perkataan, tingkah laku, dalam kasih, kesetiaan, dan menjadi teladan dalam kesucian hidup yang artinya guru harus memelihara imannya, kekudusan dirinya, dan menjauhkan diri dari berbagai perbuatan tercela. ${ }^{24}$

Dengan demikian, guru PAK adalah pendidik profesional yang memiliki bidang tugas pada mata pelajaran PAK, sama dengan guru lainnya. Perbedaan esensialnya dengan guru pada umumnya terletak pada aspek kerohanian, iman, kasih, dan pemberitaan yang disampaikannya kepada para siswa.

Ionel Ene dan Iuliana Barna menggambarkan intervensi khusus untuk seorang guru agama sebagai berikut. ${ }^{25}$

Pertama, kualifikasi akademik dan kompetensi adalah sarjana di bidang teologi, sertifikat pelatihan guru, memiliki kompetensi umum dan spesifik serta pengalaman profesional. Kedua, metode pembelajaran tidak terbatas pada pengajaran formal tetapi memromosikan metode yang merangsang iman dan sensitivitas peserta didik. Ketiga, tujuan pengajaran adalah tidak semata-mata soal kemampuan berpikir, namun yang utama adalah pembangunan spiritual. Keempat, berdoa dan mempelajari kita suci adalah inti pengajaran agama. Kelima, meskipun menggunakan kurikulum dan materi yang sama kepada semua anak di kelas, tetapi ia harus mampu beradaptasi dengan konteks dan kebetuhan khusus siswa sebagai individu dan sosial tanpa mengabaikan norma etika. Keenam, kreatif - guru memberi siswa kesempatan untuk menemukan hal-hal baru, mengajukan pertanyaan, mencari jawaban, dan terlibat dalam berbagai kegiatan. Ketujuh, motivasi - membuka jalan bagi peserta didik menuju kerohanian melalui pembentukan karakter, moral dan sosial yang sempurna adalah esensi utama memilih profesi menjadi guru

${ }^{24}$ Tim Diklat Sertifikasi Guru Pendidikan Agama Kristen di Indonesia, Panduan Pelaksanaan Pendidikan Dan Latihan Profesi Guru (PLPG) Pendidikan Agama Kristen (PAK) Di Indonesia (Jakarta: Sekolah Tinggi Teologi Jakarta, 2008), 26.

25 Ionel Ene and Iuliana Barna, "Religious Education and Teachers' Role in Students' Formation agama. Kedelapan, memberi instruksi kepada anak-anak tentang perilaku moral, agama, dan sosial adalah metode pendisiplinan yang harus diterapkan setiap saat dengan cinta, sebagai prasyarat hubungan guru-siswa. Kesembilan, memperkaya (diversifikasi) bahan pengajaran dan tidak terpaku pada bahan yang disetujui secara eksklusif. Kesepuluh, melakukan evaluasi sebagai sarana menganalisis aktivitas peserta didik sebagai tahap penilaian diri (individual) siswa di kelas secara permanen, memromosikan kerukunan, kasih dan saling menghargai (respek) antara siswa dan juga dalam hubungan guru-siswa. Terakhir, penggunaan waktu; waktu yang dihabiskan oleh anak-anak tidak terbatas pada kegiatan kelas, tetapi juga mengambil bagian dalam pelayanan di gereja serta pada berbagai acara keagamaan, sosial, dan filantropis dalam kehidupan masyarakat.

Guru memiliki banyak tugas, apabila dikelompokkan, terdapat tiga jenis tugas guru yakni tugas dalam bidang profesi, tugas kemanusiaan, dan tugas dalam bidang kemasyarakatan. ${ }^{26}$ Tugas guru secara umum di atas, juga menjadi tugas guru PAK. Perbedaanya terletak segi spiritualitas, kepribadian dan materi pelajaran yang diajarkannya. Oleh karena itu, tugas PAK juga banyak bersinggungan dengan tugas guru-guru lainnya (lih. Tim Diklat Sertifikasi Guru PAK, 2008).

Banyak peran yang disandang oleh seorang guru PAK. Peranan ini juga disandang oleh semua guru yang lain, meskipun dia tidak mengajar PAK. Namun ada tugas dan peranan yang tidak disandang oleh guru secara umum, yaitu tugas menjadi penafsir iman Kristen, menjadi seorang gembala (Pastor) bagi muridmuridnya, serta bertugas sebagai seorang penginjil, yang bertanggung jawab atas penyerahan diri setiap peserta didiknya kepada Yesus Kristus. ${ }^{27}$

\section{Komponen Spiritualitas Guru PAK}

Spiritualitas guru PAK terdiri dari 3 (tiga) subkomponen kompetensi, yakni: "memiliki

towards Social Integration," Procedia-Social and Behavioral Sciences 180 (May 2015): 30-35.

${ }^{26}$ M. Uzer Usman, Menjadi Guru Profesional (PT. Remaja Rosdakarya, 2009), 7.

${ }^{27}$ E.G. Homrighausen and I.H. Enklaar, Pendidikan Agama Kristen (Jakarta: BPK Gunung Mulia, 2005), 180181. 
kekuatan spiritualitas yang membangkitkan profesionalisme guru, memiliki semangat panggilan, dan memiliki penguasaan terhadap firman Allah sebagai sumber materi ajar." 28

Selaras dengan pendapat dan reviu litaratur tentang spiritualitas di atas, maka menurut penulis nilai-nilai spiritualitas Kristen dalam kepribadian guru PAK dapat dijabarkan dalam dua bagian, yaitu dimensi personal dan dimensi relasional. Dimensi personal merupakan hal-hal yang menyangkut pribadi dari individu, sementara dimensi relasional merupakan hal-hal yang menyangkut hubungan antara individu dengan sesamanya.

Apabila setiap dimensi tersebut dijabarkan, maka nilai-nilai spiritual yang harus dimiliki oleh seorang guru PAK dapat dijelaskan pada tabel 1 dan 2 .

\section{Internalisasi Nilai-nilai Spiritualitas Guru PAK}

Internalisasi sebagai proses pemasukan nilai pada seseorang yang akan membentuk pola pikirnya dalam melihat makna realitas pengalaman. Nilai-nilai tersebut bisa jadi dari berbagai aspek baik agama, budaya, norma sosial dan lain-lain. Pemaknaan atas nilai inilah yang mewarnai pemaknaan dan penyikapan manusia terhadap diri, lingkungan dan kenyataan di sekelilingnya. Dengan demikian proses internalisasi, adalah proses yang berlangsung sepanjang hidup individu, yaitu mulai saaat ia dilahirkan sampai akhir hayatnya. Sepanjang hayatnya seorang individu terus belajar untuk mengolah segala perasaan, hasrat, nafsu dan emosi yang membentuk kepribadiannya.

Demikian pula halnya dengan guru PAK, proses internalisasi nilai-nilai spiritualitas dalam dirinya tentunya tidak terjadi secara instan. Melainkan melalui proses yang panjang. Setidaknya hal ini dimulai sejak ia menempuh pendidikan di bangku kuliah, hingga pada hari ini ketika ia melaksanakan tugas sebagai guru PAK. Selama itu pula semestinya proses internalisasi nilai-nilai spiritualitas dalam diri seorang guru PAK terjadi.

28 Widya Yulianti, Profesionalisme, Standar Kompetensi Dan Pengembangan, ed. Saur Hasugian, 1st ed. (Bandung: Bina Media Informasi, 2009).

29 Eddy Tukidjan and Piet J. Msen, "Sekolah Sebagai Sistem Sosial" (Denpasar: Universitas
Pembangunan spiritualitas siswa dalam ruang lingkup sekolah semestinya terjadi melalui proses internalisasi. Hal ini disebabkan karena sekolah merupakan suatu sistem sosial sebagaimana dikatakan oleh Eddy Tukidjan dan Piet J. Msen bahwa "Situasi sekolah tidak jauh berbeda dengan situasi dalam masyarakat. Sekolah memiliki ciri-ciri yang serupa dengan ciri-ciri yang berada di dalam sistem sosial. Institusi sosial yang disebut sekolah itu merupakan suatu masyarakat kecil yang mempunyai kebudayaan tertentu. Kebudayaan sekolah dan interaksi antar individu yang berada di dalamnya akan melahirkan suatu sistem sosial" ${ }^{29}$

Oleh karena itu, pendidikan dalam ruang lingkup sekolah terjadi melalui proses internalisasi nilai-nilai yang terwujud melalui interaksi antara setiap individu di dalamnya. Melalui interaksi, seseorang akan meniru pandangan, gaya hidup dan spiritualitas rekan yang lain. ${ }^{30}$ Sudah tentu di sinilah dituntut agar pemimpin selalu berupaya menjadikan dirinya transparan atau dapat diamati, dan terbuka di hadapan orang-orang yang dilayaninya.

Di sini guru peranan guru sebagai contoh dan teladan ketika berinteraksi dengan rekan guru maupun siswanya sangatlah penting. Ia akan diamati, namun sekaligus menjadi pengamat proses interaksi orang-orang di dalam kelompoknya. Ia menjadi fasilitator, yang memotivasi atau memungkinkan komunikasi yang penuh makna terjadi secara baik. Ia pemimpin, namun juga sebagai anggota kelompoknya, yang dibutuhkan serta membutuhkan sesamanya. Sejalan dengan itu, ia dituntut untuk mendemonstrasikan nilai dan sikap hidup sebagai hamba di antara sesamanya sebagai wujud spiritualitasnya kepada Allah yang diimaninya, sekaligus yang menjadi pusat pengajarannya. Sehingga dengan demikian, seorang guru dapat dikatakan merupakan kurikulum yang hidup, karena seluruh kehidupannya menjadi sumber pembelajaran bagi siswanya.

Pendidikan Ganesha, n.d.), accessed May 8, 2019, http://perpustakaan.undiksha.ac.id/statistik/media.ph p? module=Buku2.

30 B. Samuel Sidjabat, Strategi Pendidikan Kristen: Suatu Tinjauan Teologis-Filosofis (Yogyakarta: Andi Offset, 1996), 93. 
Tabel 1. Nilai-nilai Spritual dalam Dimensi Pribadi Guru PAK

\begin{tabular}{|c|c|c|}
\hline Dimensi & Nilai-nilai Spiritual & Indikator \\
\hline Dimensi personal & $\begin{array}{l}\text { Relasi yang baik dengan } \\
\text { Tuhan }\end{array}$ & $\begin{array}{l}\text { - menjadi contoh dan teladan bagi siswa dalam } \\
\text { membangun relasi dengan Allah pada setiap } \\
\text { pelaksanaan kegiatan pembelajaran (Kis. 2:43-47). } \\
\text { - } \text { menjadi contoh dan teladan bagi siswa dalam } \\
\text { ibadah dan persekutuan (Ibr. 10:25). } \\
\text { - melakukan praktik-praktik spiritual seperti } \\
\text { meditasi, bersaat teduh (Mat. 14:13a; Mrk. 1:35). } \\
\text { - mengakui tugasnya sebagai pendidik merupakan } \\
\text { tugas panggilan Allah dalam kehidupannya }\end{array}$ \\
\hline
\end{tabular}

\begin{tabular}{|c|c|}
\hline $\begin{array}{l}\text { Percaya dan menerima } \\
\text { Yesus sebagai Juruselamat } \\
\text { pribadinya }\end{array}$ & $\begin{array}{l}\text { - berani mengakui Yesus sebagai Juruselamatnya dan } \\
\text { mendorong siswanya untuk menerima dan } \\
\text { mengakui Yesus sebagai Tuhan dan Juruselamat } \\
\text { pribadi mereka } \\
\text { - menjadikan Yesus sebagai teladan dalam hidup dan } \\
\text { pengajarannya }\end{array}$ \\
\hline Dipimpin oleh Roh Kudus & $\begin{array}{l}\text { - memiliki roh, jiwa, semangat dan gairah dalam } \\
\text { melaksanakan tugas mengajar } \\
\text { - berhikmat atau bijaksana dalam menghadapi } \\
\text { berbagai persoalan, baik persoalan pribadi mau pun } \\
\text { yang berhubungan dengan tugas-tugasnya sebagai } \\
\text { guru (Yes. 33:6; Ef. 1:17)) } \\
\text { - rajin melaksanakan tugas-tugas sebagai pengajar } \\
\text { (memiliki etos kerja sebagai pendidik) } \\
\text { - percaya diri ketika mengajar di depan siswanya }\end{array}$ \\
\hline $\begin{array}{l}\text { Memiliki kehidupan yang } \\
\text { berpusat pada Allah } \\
\text { Tritunggal }\end{array}$ & $\begin{array}{l}\text { menjadikan Allah Tritunggal sebagai pusat } \\
\text { pengajarannya }\end{array}$ \\
\hline $\begin{array}{l}\text { Berpegang pada ajaran } \\
\text { Alkitab }\end{array}$ & $\begin{array}{l}\text { - menjadikan Alkitab sebagai dasar pengajarannya (2 } \\
\text { Tim. 3:16) } \\
\text { - mampu memberikan penafsiran terhadap firman } \\
\text { Tuhan sesuai dengan prinsip-prinsip hermenutik }\end{array}$ \\
\hline $\begin{array}{l}\text { Memiliki keyakinan } \\
\text { kepada Allah yang } \\
\text { diimaninya }\end{array}$ & $\begin{array}{l}\text { - berani menyampaikan kesaksian iman dan } \\
\text { mendorong siswa untuk menyampaikan kesaksian } \\
\text { imannya sesuai dengan topik pembelajaran yang } \\
\text { sedang berlangsung } \\
\text { - senantiasa mendorong siswa untuk mempercayakan } \\
\text { kehidupan dan pergumulannya ke dalam tangan } \\
\text { Tuhan } \\
\text { - mendorong siswa untuk meyakini bahwa Allah } \\
\text { mampu menyelesaikan pergumulannya }\end{array}$ \\
\hline $\begin{array}{l}\text { Menjaga kekudusan atau } \\
\text { kesucian hidup }\end{array}$ & $\begin{array}{l}\text { - menjauhkan diri dari hal-hal yang bertentangan } \\
\text { dengan ajaran Kristus, misalnya: pesta pora, mabuk- } \\
\text { mabukan, memamerkan kekayaan, terlibat } \\
\text { prostitusi, dll. (Roma 13:13). } \\
\text { - menjunjung tinggi ajaran dan aturan gereja (tidak } \\
\text { pernah dikenakan siasat gereja). }\end{array}$ \\
\hline
\end{tabular}




\begin{tabular}{|c|c|}
\hline Memiliki tujuan hidup & $\begin{array}{l}\text { - } \text { memiliki visi dan misi dalam hidupnya } \\
\text { menunjukkan arah yang benar bagi kehidupan } \\
\text { siswanya dengan memberi nasehat, menegur, } \\
\text { mengkritik dan membimbing (I Ptr. 2:9; Mrk 12:29- } \\
\text { 30). } \\
\text { - } \\
\text { senantiasa memotivasi siswanya untuk belajar } \\
\text { dengan baik. } \\
\text { menjadi motivator bagi kehidupan pribadi } \\
\text { siswanya }\end{array}$ \\
\hline $\begin{array}{l}\text { Memiliki relasi yang baik } \\
\text { dengan sesama makhluk } \\
\text { ciptaan Tuhan }\end{array}$ & $\begin{array}{l}\text { memiliki hubungan yang baik dengan setiap } \\
\text { anggota keluarganya (memiliki latar belakang } \\
\text { keluarga yang baik) (1 Tim. 3:1-7) } \\
\text { membangun kerjasama yang baik dengan orang } \\
\text { lain } \\
\text { memelihara dan melestarikan alam semesta dengan } \\
\text { menjadi teladan bagi siswa dan rekan kerjanya } \\
\text { melalui tindakan nyata seperti: tidak membuang } \\
\text { sampah sembarangan, mengkoordinir pelaksanaan } \\
\text { kerja bakti, dan sebagainya (Kej. 1:28). }\end{array}$ \\
\hline Berpikir positif & $\begin{array}{l}\text { - tidak berprasangka buruk/curiga kepada siswa } \\
\text { dan rekan kerjanya } \\
\text { - } \quad \text { mampu mengambil pelajaran yang berharga dari } \\
\text { suatu kegagalan } \\
\text { - bersikap optimis dalam kehidupannya }\end{array}$ \\
\hline
\end{tabular}

Tabel 2. Nilai-nilai Spritual dalam Dimensi Relasional Guru PAK

\begin{tabular}{|c|c|c|}
\hline $\begin{array}{l}\text { Dimensi } \\
\text { relasional }\end{array}$ & Sabar & $\begin{array}{l}\text { - } \quad \text { mampu menghadapi berbagai tingkah laku siswa } \\
\text { (Kol. 3:12-13). }\end{array}$ \\
\hline & $\begin{array}{l}\text { Bersikap fleksibel dan } \\
\text { menyesuaikan diri dengan } \\
\text { lingkungan }\end{array}$ & $\begin{array}{l}\text { - mampu mengelola kelas dengan baik } \\
\text { - menjadi sahabat bagi siswanya } \\
\text { - menghargai rekan kerja } \\
\text { - loyal kepada pimpinan } \\
\text { - metode pembelajaran dilaksanakan secara kreatif } \\
\text { dan variatif. }\end{array}$ \\
\hline & Emosi stabil & $\begin{array}{l}\text { - tidak menjadikan siswa sebagai pelampiasan } \\
\text { pergumulan atau permasalahan pribadinya. }\end{array}$ \\
\hline & $\begin{array}{l}\text { Kuat dan tabah } \\
\text { menghadapi penderitaan } \\
\text { dan rasa sakit }\end{array}$ & $\begin{array}{l}\text { - tidak mudah menyerah, mengeluh atau bersungut- } \\
\text { sungut. }\end{array}$ \\
\hline & Mandiri & 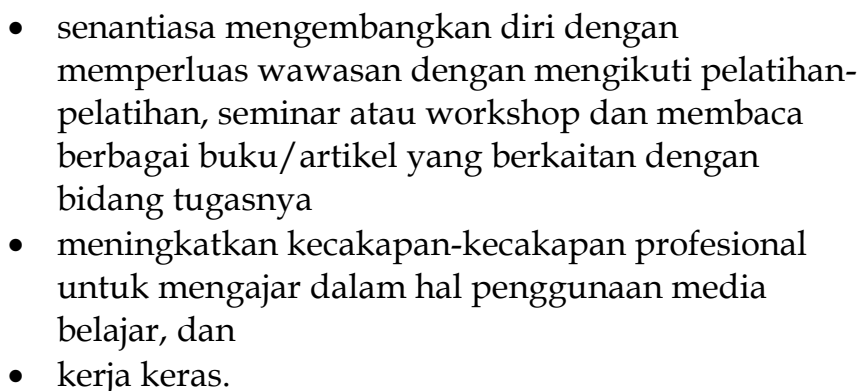 \\
\hline
\end{tabular}




\begin{tabular}{|c|c|}
\hline Setia & $\begin{array}{l}\text { - menyelesaikan tugas sampai tuntas } \\
\text { - tidak meninggalkan pekerjaan begitu saja, dan } \\
\text { - siap ditempatkan atau ditugaskan di mana saja }\end{array}$ \\
\hline Bertanggungjawab & $\begin{array}{l}\text { - siap menghadapi resiko } \\
\text { - tidak melemparkan kesalahan kepada orang lain } \\
\text { - menyelesaikan tugas tepat waktu. }\end{array}$ \\
\hline Sukacita & $\begin{array}{l}\text { - } \text { menyenangkan (1 Sam. 2:26) } \\
\text { - } \text { raut muka berseri-seri atau tidak murung (Amsal } \\
\text { - mampu menyampaikan kata-kata penghiburan } \\
\text { kepada siswa yang mengalami kesedihan (2 Kor. } \\
\text { 2:7). }\end{array}$ \\
\hline Damai sejahtera & $\begin{array}{l}\text { - tidak menghasut/memprovokasi siswa dengan } \\
\text { berbagai isu (Gal. 5:12) } \\
\text { - menjadi penengah/juru damai bagi siswa yang } \\
\text { bermasalah (Mat. 5:9) } \\
\text { - mampu merangkul seluruh siswanya dalam } \\
\text { kesatuan (Yoh. 17:21; Kol. 3:14), dan } \\
\text { - tidak membebani pikiran orang lain. }\end{array}$ \\
\hline Murah hati & $\begin{array}{l}\text { - mengasihi siswa-siswanya (Im. 19:18; Luk. 10:27) } \\
\text { - menaruh simpati dan empati terhadap siswanya } \\
\text { - } \text { diskriminatif (Ul. 16:20; Mikha 6:8), dan } \\
\text { - dapat memperlakukan orang lain dengan baik } \\
\text { sebagaimana ia juga ingin diperlakukan baik oleh } \\
\text { orang lain }\end{array}$ \\
\hline Kasih & $\begin{array}{l}\text { - } \text { mengasihi siswa-siswanya (Im. 19:18; Luk. 10:27) } \\
\text { - menaruh simpati dan empati terhadap siswanya } \\
\text { diskriminatif (Ul. 16:20; Mikha 6:8), dan } \\
\text { - dapat memperlakukan orang lain dengan baik } \\
\text { sebagaimana ia juga ingin diperlakukan baik oleh } \\
\text { orang lain }\end{array}$ \\
\hline $\begin{array}{l}\text { Berperilaku etis sesuai } \\
\text { dengan nilai-nilai Kristiani }\end{array}$ & $\begin{array}{l}\text { - berpakaian sopan dan rapi } \\
\text { - bertutur kata baik } \\
\text { - tidak berbicara kasar sehingga melukai perasaan } \\
\text { atau mematahkan semangat peserta didik, dan } \\
\text { - sopan satun atau memiliki tatakrama yang baik (1 } \\
\text { Kor. 14:40). }\end{array}$ \\
\hline
\end{tabular}

Hal ini sejalan dengan peribahasa Nias yang mengatakan " mangumaö daromali, mango'ou mbuabua", yang berarti teori atau kata-kata dapat mengajar, tetapi perbuatan mendorong orang lain yang melihatnya untuk turut berbuat. Sebab itu jika guru PAK ingin agar siswanya memiliki spiritualitas yang baik, maka ia tidak boleh hanya mengajar mereka dengan kata-kata saja, tetapi juga dengan perbuatannya.

\section{SIMPULAN}

Guru PAK adalah pendidik profesional yang memiliki tugas dalam mata ajar Pendidikan Agama Kristen. Yang membedakannya dari guru lain terletak pada dimensi spiritualitas, kasih, dan pengajarannya. Sebagai profesional, seorang guru PAK memiliki peran unik sebagai penafsir iman Kristen, gembala bagi muridmuridnya, dan melayani sebagai penginjil, yang bertanggung jawab atas penyerahan masingmasing muridnya kepada Yesus Kristus. 
Pendidikan Agama Kisten bertujuan agar agar manusia mengalami hidupnya sebagai respon terhadap kerajaan Allah di dalam Yesus Kristus, serta menumbuh-kembangkan iman serta kemampuan siswa untuk dapat memahami dan menghayati kasih Allah dalam Yesus Kristus yang dinyatakan dalam kehidupan sehari-hari. Tujuan pendidikan atau pmbelajaran itu hanya dapat tercapai secara maksimal jika guru PAK memiliki seperangkat kompetensi, di antaranya kompetensi kepribadian. Untuk menguatkan kompetensi kepribadian itu, seorang guru PAK harus memiliki spiritualitas yang baik. Nilai-nilai spiritualitas dalam kompetensi kepribadian itu, akan terlihat pada dimensi pribadi dan dimensi relasional dalam melaksanakan tugas dan tanggungjawabnya sebagai guru PAK.

Kehidupan nyata seorang guru bagai buku terbuka yang dapat dibaca oleh semua orang, termasuk siswa-siswinya. Aspek ini saling kait mengkait dengan penilaian siswa terhadap kepribadian guru PAK, artinya keteladanan yang ditunjukkan oleh guru PAK akan diikuti oleh siswa pada umumnya. Permasalahan akan timbul jika keteladanan tidak mampu ditunjukkan oleh guru PAK. Akibatnya penilaian siswa terhadap guru menjadi kurang baik dan mampu menyebabkan menurunnya minat atau motivasi siswa untuk bertumbuh dalam iman kepada Tuhan.

"Don't try to fix the students, fix ourselves first. The good teacher makes the poor student good, and the good student superior. When our students fail, we, as teachers too have failed". ${ }^{31}$ Pernyataan ini menunjukkan bahwa seorang guru yang baik terlebih dahulu harus lebih baik daripada muridmuridnya. Jika ia mengharapkan siswanya menjadi baik, maka ia harus jauh lebih baik dari mereka, dan jika ia mau siswanya yang sudah baik menjadi unggul, maka guru tersebut harus lebih unggul dari mereka. Ketika siswa menjadi gagal, berarti guru tersebut telah gagal menjadi guru.

\section{REFERENSI}

Artanto, Widi. "Spiritualitas Pelayanan: Perjumpaan Dengan Allah Dan Sesama." In Pelayanan, Spiritualitas Dan Pelayanan, edited by Asnath N. Nathar, 7. Yogyakarta: Taman

31 Marva Collins, "The Outstanding Educator," Bleacherreport.Com, last modified 2008, accessed May 13,
Pustaka Kristen, 2012.

Collins, Marva. "The Outstanding Educator." Bleacherreport.Com. Last modified 2008. Accessed May 13, 2019. https://bleacherreport.com/articles/53191marva-collins-the-outstanding-educator.

Darmaputera, Eka. Spiritualitas Siap Juang. Jakarta: BPK Gunung Mulia, 2011.

Eliade, Mircea. The Encyclopedia of Religion. 3rd ed. New York: Macmillan Publishing, 1986.

Emmons, Robert A., and Cheryl A. Crumpler. "Religion and Spirituality? The Roles of Sanctification and the Concept of God." The International Journal for the Psychology of Religion 9, no. 1 (January 16, 1999): 17-24. http://www.tandfonline.com/doi/abs/10.1 207/s15327582ijpr0901_3.

Ene, Ionel, and Iuliana Barna. "Religious Education and Teachers' Role in Students' Formation towards Social Integration." Procedia - Social and Behavioral Sciences 180 (May 2015): 30-35.

Harjanto, V. Wahyu. Berbakti Dengan Spirit Dan Nalar: Spiritualitas Atau Teologi? Orientasi Baru. Jurnal Filsafat Dan Teologi. Yogyakarta: Kanisius, 2001.

Hill, Peter C., Kenneth II. Pargament, Ralph W. Hood, Jr., Michael E. McCullough, James P. Swyers, David B. Larson, and Brian J. Zinnbauer. "Conceptualizing Religion and Spirituality: Points of Commonality, Points of Departure." Journal for the Theory of Social Behaviour (2000).

Homrighausen, E.G., and I.H. Enklaar. Pendidikan Agama Kristen. Jakarta: BPK Gunung Mulia, 2005.

Hulu, Etty Destinawati. “Spiritualitas Guru Pendidikan Agama Kristen Dan Pengaruhnya Terhadap Pencapaian Tujuan Pembelajaran." STT Banua Niha Keriso Protestan Sundermann Nias, 2014.

Krippendorff, Klaus. Content Analysis: An Introduction to Its Methodology (Second Edition). SAGE Publications, 2004.

Kriyantono, Rachmat. Teknik Praktis Riset Komunikasi. 6th ed. Jakarta: Kencana Prenada Media Grup, 2012.

Lewis, E. "Posture as a Metaphor for Biblical Spirituality." In The Destructive Power of Religion: Violence in Judaism, Christianity and

2019, https://bleacherreport.com/articles/53191-marvacollins-the-outstanding-educator. 
Islam, edited by J. Ellens, 4:143-174. Westport, CT: Praeger, 2004.

McGrath, Alister E. Christian Spirituality: An Introduction. Oxford: Blackwell Published, 1999.

Nelson, James M. Psychology, Religion, and Spirituality. Edited by James M. Nelson. New York, NY: Springer New York, 2009. http://link.springer.com/10.1007/978-0-38787573-6.

Rizzuto, Ana-María. "Psychoanalytic Considerations about Spiritually Oriented Psychotherapy." In Spiritually Oriented Psychotherapy., 31-50. Washington: American Psychological Association, 2005. http://content.apa.org/books/10886-002.

Roehlkepartain, Eugene C., Peter L. Benson, Pamela Ebstyne King, and Linda M. Wagener. "Spiritual Development in Childhood and Adolescence: Moving to the Scientific Mainstream." In The Handbook of Spiritual Development in Childhood and Adolescence, edited by E. Roehlkepartain and P. King, 1-15. 2455 Teller Road, Thousand Oaks California 91320 United States: SAGE Publications, Inc., 2006.

http://sk.sagepub.com/reference/hdbk_chil dspiritdev/n1.xml.

Sheldrake, Philip. "Spirituality: A Brief History." In Statewide Agricultural Land Use Baseline 2015, 23-46. 2nd ed. Somerset, New Jersy: John Wiley and Sons, 2013.

- - - . The New SCM Dictionary of Christian Spirituality. SCM Press, 2005.

Sidjabat, B. S. Mengajar Secara Profesional: Mewujudkan Visi Guru Profesional. Yayasan Kalam Kudus, 2009.

Sidjabat, B. Samuel. Strategi Pendidikan Kristen: Suatu Tinjauan Teologis-Filosofis. Yogyakarta: Andi Offset, 1996.

Takahashi, Masami, and Satoshi Ide. "Implicit Theories of Spirituality across Three Generations: A Cross-Cultural Comparison in the U.S. and Japan." Journal of Religious Gerontology (2003).

Tanudjaja, Rahmiati. "Anugerah Demi Anugerah Dalam Spiritualitas Kristen Yang Sejati." Veritas, no. 2 (October) (2002): 171-182.

Tim Diklat Sertifikasi Guru Pendidikan Agama Kristen di Indonesia. Panduan Pelaksanaan Pendidikan Dan Latihan Profesi Guru (PLPG) Pendidikan Agama Kristen (PAK) Di Indonesia.
Jakarta: Sekolah Tinggi Teologi Jakarta, 2008.

Tukidjan, Eddy, and Piet J. Msen. "Sekolah Sebagai Sistem Sosial." Denpasar: Universitas Pendidikan Ganesha, n.d. Accessed May 8, 2019.

http://perpustakaan.undiksha.ac.id/statistik /media.php?module=Buku2.

Usman, M. Uzer. Menjadi Guru Profesional. PT. Remaja Rosdakarya, 2009.

Yulianti, Widya. Profesionalisme, Standar Kompetensi Dan Pengembangan. Edited by Saur Hasugian. 1st ed. Bandung: Bina Media Informasi, 2009.

Zinnbauer, Brian J., Kenneth I. Pargament, Brenda Cole, Mark S. Rye, Eric M. Butter, Timothy G. Belavich, Kathleen M. Hipp, Allie B. Scott, and Jill L. Kadar. "Religion and Spirituality: Unfuzzying the Fuzzy." Journal for the Scientific Study of Religion 36, no. 4 (December 1997):

549. https://www.jstor.org/stable/1387689?origi $\mathrm{n}=$ crossref.

Zohar \& Marshall, and Jenny King. "SQ: Spiritual Intelligence: The Ultimate Intelligence." Psychology and Psychotherapy 75, no. January (2002): 116-117. 